\title{
Postmodern Political Discourse: A Thematic and Linguistic Analysis of Mandela's Long Walk to Freedom
}

\author{
Mukhtiar Muhammad $^{1} \&$ Farheen Ahmed Hashmi ${ }^{1}$ \\ ${ }^{1}$ Faculty of English Studies, National University of Modern Languages, Islamabad, Pakistan \\ Correspondence: Mukhtiar Muhammad, Faculty of English Studies, National University of Modern Languages, \\ Islamabad, Pakistan. E-mail: mm8444484@gmail.com
}

Received: December 16, 2019

Accepted: January 23, 2020 Online Published: February 5, 2020

doi:10.5539/ijel.v10n2p198

URL: https://doi.org/10.5539/ijel.v10n2p198

\begin{abstract}
The Postmodern wave of democratization and the emphasis on democratic values and right to expression make it imperative that the political discourse be studied with more and full attention. In this regard, one genre that is almost totally ignored in Pakistani context and little attention has been paid to it even at the global level, is autobiography. Autobiography is a special kind of composition in which the author gives a picture of the evolution of the self and its relation with the external world throughout this evolutionary process. The famous political autobiography Long Walk to Freedom by Nelson Mandela is, therefore, selected as the basic unit of analysis. Through content analysis different topics are separated from the original text. These topics are then grouped under different categories of van Dijk's theory of Political Discourse Analysis (PDA). The exploration and analysis of linguistic devices are also carried out. Besides Van Dijk's PDA, Huckin's approach to text and Corpus Linguistics' quantitative methodology aided the systematic in-depth analysis. Methods of both qualitative and quantitative research have been utilized for this study as the researchers believe that quantification of data along with qualitative description produce reliable results. Findings revealed various linguistic devices are used in abundance. Amongst the most prominent ones are the unique and effective use of the year-statistics, language of the minority regime, Afrikaans, Trilingual combination, dramatic language and listing or cluster of three to stress certain themes like racial discrimination, inequality, poverty, parties, law, justice, separation and history.
\end{abstract}

Keywords: autobiography, corpus linguistics, linguistic devices, Nelson Mandela, political discourse, themes

\section{Introduction}

\subsection{Language, Discourse and Discourse Analysis}

Language, one of the distinguishing features of Homo sapiens has been the subject of study not only during the modern and postmodern eras but it goes back into the pages of ancient history to Panini and Greek scholars. Man, variously called as a social animal, a tool making animal, is also called a talking animal. Through this unique tool, man conveys his message to others. With the passage of time man devised different methods to convey his message in a clear way, manipulating at the same time the language for his own special purpose. He also emphasized or deemphasized certain topics or themes, that is, recurrently occurring topics. This moved the study of language towards discourse.

The term discourse is applied to both written and spoken language. Discourse is an institutionalized and specialized way of speaking and writing that specifies what people say and write, how they say it and what not to say (Johnson, 2005). It also determines what they do not express openly or do not say. Discourses utilize a unified choice of words with symbols and specific metaphors that help us to construct and communicate a coherent interpretation of reality. According to Fairclough (1995), discourses include representations of how things are and have been, as well as imaginary representations of how things might or could or should be. The knowledge of the knowledge-economy and knowledge-society are imaginaries in this sense, projections of possible states of affairs and possible world.

For macro analysis of discourses, discourse analysis (DA) is used. Discourse analysis is defined by Crystal (1994) as the study of continuous stretches of language longer than a single sentence. It is also called discourse linguistics and specially investigates the organization of such general notions as conversations, arguments, narratives, jokes, 
and speeches, looking out in particular for linguistic features which identify structure of discourse (discourse markers), such as I mean to say or well, anyway.

On the other hand, critical discourse analysis aims at micro analysis of discourses. Van Dijk (2015) defines critical discourse analysis (CDA) as a type of discourse analytical research that primarily studies the way social power abuse, dominance, and inequality are enacted, reproduced, and resisted by text and talk in social and political context. With such dissident research, critical discourse analysts take explicit position, and thus want to understand, expose, and ultimately resist social inequality.

\subsection{Political Discourse and Its Analysis}

What exactly is political discourse? The easiest, and not altogether misguided, answer is that political discourse is identified by its actors or authors, viz., politicians. Indeed, the vast bulk of studies of political discourse is about the text and talk of professional politicians or political institutions, such as presidents, prime ministers and other members of government, parliament or political parties, both at the local, national and international levels (Van Dijk, 1997).

The economic and political situation at global level and emerging indigenous political situation in Pakistan make it necessary to study lives and discourses of political actors in the world and in Pakistan. In addition, politics in postmodern world, especially in post 9/11 scenario, requires further research in order to understand political discourse and politics at global as well as indigenous level.

Primarily, the researchers were concerned with a fact that many people did not fully grasp political discourse. This necessitated further systematic research in this area. Preliminary survey also revealed that political autobiographies have been scarcely studied from political discourse perspective. Autobiographies as personal histories provide firsthand knowledge about the author, original language and act as primary sources of information.

Political discourse analysis (PDA), which is relatively a new discipline in the field of analysis, according to Van Dijk (1998) is a critical analysis of political discourses. He includes the whole discipline of political science for political discourse analysis. Main interest of the researchers in this study was to fully analyze the selected autobiography in the frame of Van Dijk's Model of Political Discourse Analysis. Where necessary, parts of Van Dijk's Socio-Cognitive Model are also utilized to discuss recurrent themes and linguistic devices used in the autobiography and compare and contrast them, in order to better understand current political dialogue in the world and Pakistan.

\subsection{Selection of Genre of Political Autobiography for Research}

Although the desire of expressing oneself is very old, especially self-expression or writing about oneself, that is, the expression of the "self", the channel that expresses the self was not given due attention. Weintraub (1975) in his paper "Autobiography and Historical Consciousness" states "An autobiographic instinct may be as old as Man Writing; but only since 1800 has Western Man placed a premium on autobiography. A bibliography of all the autobiographic writing prior to that time would be a small fascicule; a bibliography since 1800 a thick tome" (p. 821).

An autobiography does have a scope to be exploited for the study of political discourse and for the discovery of the themes, especially political themes. The language of this genre can also be studied for the linguistic devices that the politicians and statesmen use in their autobiographies to convey or communicate their intended message to the readers and to the world at large. This genre is utilized very little for the analysis of discourse even until recently the genre itself had not been given attention. As Weintraub (ibid.) says:

Since the word "autobiography" by its derivation, means no more than the life recorded is the life lived by the writer, the reach of the term is very wide. Lyric poetry can hardly be free of its strongly autobiographical elements; yet it makes no sense to let this great poetic genre be swallowed up by in the imperialistic overreach of a loosely defined term. The autobiographic factor in such poetry very rarely is "a life," more frequently but a moment of life, and only sometimes indeed it is a significant moment summing up the quintessential meaning of a life. The individual can sum up his life on a tombstone, but here the rendition of a life awesomely brief; when it is longer, it rather tends to become the record state than a private document. Even if no such criterion is hard and fast, it seems sensible at least, to demand that autobiography has scope. It is expected to have recaptured a significant segment of life, a formidable portion of an experience (p. 822).

Research and analysis of autobiography as a distinct genre still needs a lot of work, especially in the South African and Asian regions. This discussion provides the initial stage for problem to be brought to the fore. In 
order to investigate the problem, the researchers started analysis of various political autobiographies. In this process, critical discourse analysis which is of paramount importance was carried out on a small sample. The analysis provided sufficient background to the researchers to start a systematic research inquiry in the said field. The content of these autobiographies was found to be rich in different political themes and the use of various linguistic devices to communicate these themes.

\subsection{Need for Research in Neo-Political Discourses}

After the world war second, there had been great changes in the political and geographical maps of the world. Europe, affected economically and politically by the blows of the Great War, could no longer control its colonies in Africa and Asia and in other parts of the world. The formation of the consultative body at the global level, United Nations Organization (UNO), also speeded up the process of decolonization. The signing of human rights charters also led towards new politics in the world. The struggle movements in Africa and Asia got momentum. Many countries achieved their independence in the 1940's and others accelerated their struggles. In fifties and especially in sixties, the freedom movements and the human rights demands like black people's struggle for independence in Africa, especially in South Africa where African National Congress and other organizations accelerated their efforts. In the same manner, in the United States of America, people like Martin Luther King appeared as the flag bearers of such movements.

The discourse of these freedom and human rights movements also went through drastic changes. This change was felt by the researchers during the preliminary study of this "new" discourse, especially the "neo-political discourses" of these struggling leaders. For this purpose, the researchers wanted to study in detail these discourses and select a personality relevant in history and continuity of these struggles. Nelson Mandela, who spent more than twenty-seven years in prison and ultimately succeeded to become the first black president of the republic of South Africa, was therefore selected.

Table 1. Selection of unit of analysis

\begin{tabular}{|c|c|c|c|c|}
\hline S.\# & Political Actor & Autobiography & Political Philosophy & Context \\
\hline 1. & Nelson Mandela & Long Walk to Freedom & $\begin{array}{ll}- & \text { Change } \\
- & \text { Freedom } \\
- & \text { New Age }\end{array}$ & Black African against White dominance \\
\hline
\end{tabular}

\subsection{Nelson Mandela and Long Walk to Freedom}

Nelson Mandela, born 18th July, 1918, is one of the political figures and freedom fighters in the contemporary world. On his birth, he was given the name Rolihlahla which in his native Xhosa language literally means "pulling the branch of a tree" or simply "troublemaker". The English name "Nelson" was given to him by his teacher in school. In his early childhood, he was raised in the traditional way of his forefathers undisturbed by the happenings in the country beyond his small world of Xhosa land. But soon this period of peace and joy ended when he came across the system of Apartheid. He joined the African National Congress (ANC) which began his active role in the politics of his country, the central role in the struggle against racial discrimination and the system of Apartheid. Mandela also played active role in the formation of the Youth wing of ANC and its military wing Umkhonto we Sizwe. He received global recognition and fame when he raised his voice against racial oppression and Apartheid in the white dominated South Africa. In recognition of his long struggle for freedom and human rights, he was awarded Nobel Prize for peace after his release from prison in 1990. He remained in prison for twenty-seven years on Robben Island after the Rivonia Trial in 1964. In 1994, Nelson Mandela became the first black president of South Africa after the democratic elections which began a new era in the history of the country.

Long Walk to Freedom was published in 2003 by Abacus, London. In the book, Mandela narrates the story of his life right from his birth till the end of Apartheid. He tells us about his birth, early days, schooling and his family life. Mandela also narrates his arrival in Johannesburg and his early activities and difficulties there. He details his first confrontation with the Apartheid system, his joining of the ANC, his role in the ANC, the Rivonia Trial, and imprisonment on the Robben Island for twenty-seven years and his release in 1990. The book consists of eleven parts with one hundred and fifteen sub-parts or chapters.

\subsection{Objectives of Research}

1) To study the political discourse through the autobiography of the freedom and civil rights leader 
2) To identify frequently referred to political themes in the selected political autobiography

3) To explore linguistic devices that are most frequently used in order to convey these themes

\subsection{Significance of Research}

In the postmodern world of disturbing political issues, political economy and information highways, that is, the quick dispersal of information, especially political ideologies in political discourses provide strong justification for the present study in order to analyze political discourse and understand its essence. This study is especially significant because it points out recurrent trends and themes by putting them in the historical context along with various linguistic devices used to communicate these themes in the political discourse in the postmodern era. This will in turn help politicians and other stakeholders in politics and the common people understand political discourse at national and international levels. The study will in this way also help grasp future trends and themes in politics through better comprehension of language in politics.

\subsection{Delimitation of the Study}

This study is delimited to political discourse in political autobiography of political actor representing "change", "non-traditional politics" with emancipatory agenda. Rationale behind selecting this political personality is that it represents in one way or the other, the concept of "change" in politics and has "futuristic" point of view for the new political world. The study is also delimited to the exploration of themes and linguistic devices through the use of CDA methodology and AntConc.

\section{Procedure of the Study}

\subsection{Systematic and Repeated Readings}

A systematic plan was developed for thorough and repeated readings of the selected text. To have a complete feel, the autobiography was read five times. First reading was quick like an ordinary reader in order to know the overall structure and have an initial introduction in the overall framing of the text. Second reading was not just skimming but a deep reading with a critical eye. The third and fourth readings were with the same critical mind but with greater intensity. In the fifth reading, topics and relevant portions of the text were underlined/marked.

\subsection{Systematic Presentation of Raw Data}

For systematic presentation of raw data, the relevant parts of the original text and the topics marked in the previous step were presented in the tabulated form (due to limited space, these tables have not been presented here) with:

a. Left column captioned Page No. provides specific page number of the relevant part.

b. Middle column titled as Words/phrases/sentences/paragraph contains words, phrases, sentences or paragraphs from the original text and indicates where the topic in the original text appears.

c. Right column captioned as Topics presents the topics separated from the original text.

\subsection{Clustering of Topics into Themes \& Consolidation of Frequencies}

The topics separated from the three-column table are then presented for clarity in the paragraph form and clustered into themes in the frame of van Dijk's Political Discourse Analysis. Here the data are presented in the three-column table (see Table 3) with:

a. Left column captioned as Main Field presents the categories given in van Dijk's theory of Political Discourse Analysis.

b. Middle column titled as Topics under the category/theme clusters all relevant topics which come under the specific category/theme.

c. Right column is captioned as Total presents total frequency/percentage of the topics which come under a particular category or theme. This column gives us the relative strength of the category/theme.

\subsection{Use of Corpus Linguistics Techniques}

The modern techniques of Corpus Linguistics for data mining and exploring themes are utilized in dealing with large bodies of text or discourses in an efficient manner for less time consumption. Tenorio (n.d.) says this about the use of techniques of Corpus Linguistics:

Finally, it has been argued that the use of corpus linguistics techniques in CDA may help to avoid or reduce researcher bias. Quantitative computer-aided corpus approaches can address large data sets, and the focus of analysis can take into account collocations, keyness, semantic preference and semantic prosody. What 
appears to be obvious and is taken-for-granted are checked against the data at the same time that unexpected findings arise in the procedures of description and analysis.

Patterns of preferred and dispreferred lexis and structures (Baker, 2006) facilitate detecting of the ideologies of hegemonic discourses associated with particular text. The limitations of corpus approaches to CDA are that they work with very little context, may hinder close reading and can help us learn only about the verbal domain. Corpus-informed CDA can give the impression that it is a mechanistic or positivist approach. O'Halloran and Coffin's (2004) discussion of over- and under-interpretation counters the views, however.

\subsection{Use of Concordancer AntConc}

For the analysis of linguistic devices and statistical data, software AntConc is used. This software was developed in 2011 by Laurence Anthony, director at Center for English Language Education in Science and Engineering, School of Science and Engineering, Waseda University, Tokyo, Japan. AntConc is specially used in Corpus Linguistics and is a multiplatform tool used for research and data-driven learning. Actually, AntConc is a concordancer, that is, a computer program that automatically constructs a concordance, i.e., a specific list of those words from the text or a set of text under study which may serve as a rich source of data for research. The software shows the words in the context and the format in which these words are presented is called KWIC format (Key Word in Context).

\section{Data Presentation and Analysis}

\subsection{Step 1: Key Facts About the Text of Long Walk to Freedom}

There are total 11 parts and 115 sub-parts in the book. Before going into the details of the themes and linguistic devices used by Nelson Mandela, the key facts about the text of Long Walk to Freedom were collected through the use of Concordancer AntConc.

Table 2. Key facts about text of Long Walk to Freedom

\begin{tabular}{lll}
\hline S. No. & Key facts & Number in Figures \\
\hline 1. & Pages & 631 \\
2. & Word tokens & 259330 \\
3. & Word types & 16000 \\
4. & Characters (no spaces) & 1164317 \\
5. & Characters (with spaces) & 1408087 \\
6. & Paragraphs & 3984 \\
7. & Lines & 22423 \\
\hline
\end{tabular}

In Corpus Linguistics, a word token is defined as individual occurrence of a word or linguistic unit in a piece of writing or speech and a word type is not the actual occurrence but an abstract class of linguistic unit in a piece of writing or speech. In addition to the numerical facts presented above, total topics and related words separated by the researchers are 38313 . These statistics give us access to the total items or words of the unit of analysis and help in the analysis of the text.

\subsection{Step 2: Long Walk to Freedom: Representative Topics and Themes}

Due to space constraint, the detailed discussion on representative topics and themes only for first four parts is presented here. However, Step 3 will provide clustering of overall topics and themes and their total frequency.

\subsubsection{Part One: A Country Child}

a. Sub-parts: $1-8$, Pages: $3-70$

Suitably titled, "A Country Child", the very first part sets a foundation for the whole structure of the story to come. The author, right from his birth, explains the circumstances in which he was born to a respectable family and raised by an influential figure that had strong relations with his family. The author tries to use words that predict a drama and a stir in the then socio-political and economic set up. Writing about his strong physical body and his African name "Rolihlahla" meaning 'troublemaker', he actually gives us a prologue to a long eventful journey through which he was destined to go. The first part revolves around the origin, family and the factors that were going to mold his personality and pave the way for his great and unique role in the history of his country. Graphically, the start of the dramatic journey of the author is presented as follows:

1918 - birth of Rolihlahla, the troublemaker $\rightarrow$ Death of his father $\rightarrow$ Role of his mother $\rightarrow$ Going to a new 
abode, real mold of his personality $\rightarrow$ Education $\rightarrow$ Marriage matters $\rightarrow$ Catalyst for escape

b. Topics related to Categories of Childhood, Family and Race

From the very outset a controlled and conscious use of language and linguistic devices dressing of the intended theme is felt. Van Dijk's theory (1997) of political discourse analysis discusses political discourse in the shape of the personal texts or speeches of the politicians. Van Dijk (1997) believes that political discourse has a very important function of producing, abusing, resisting, and maintaining power. Here, in this unit of analysis and especially, in this very first part, the author paves the way for the reader to be ready for resistance discourse in the long textual journey he is prepared to go through. The special mention of the family, family relations, physical strength, and white man gives us a feel of conflict, inclusivity and exclusivity which will result in discourse of resistance. Throughout the long discussion in the book, Nelson Mandela could not detach himself from this discourse of resistance. The combination of the selection of themes and the conscious selection of words and phrases create this resistance-effect. Examples of the words and phrases that create resistance-effect are ancestry, race, family, foreign rule, hostile relations, the White government, family relations, early liberty/freedom, free happy days, sense of humiliation, cruelty and honour, identity, education, dealing with Whites, regent/elder against decision, brotherhood/friendship, social and political advancement. Around these words and phrases almost the whole story revolves throughout the text.

Look at the examples from the text:

APART FROM LIFE, a strong constitution, and an abiding connection to the Thembu royal house, the only thing my father bestowed upon me at birth was a name, Rolihlahla. In Xhosa, Rolihlahla literally means "pulling the branch of a tree," but its colloquial meaning more accurately would be "troublemaker". I do not believe that names are destiny or that my father somehow divined my future, but in later years, friends and relatives would ascribe to my birth name the many storms I have both caused and weathered. My more familiar English or Christian name was not given to me until my first day of school. But I am getting ahead of myself (p. 1).

Another example is as follows:

My father's response bespoke his belief that the magistrate had no legitimate power over him. When it came to tribal matters, he was guided not by the laws of the king of England, but by Thembu custom. This defiance was not a fit of pique, but a matter of principle. He was asserting his traditional prerogative as a chief and was challenging the authority of the magistrate. When the magistrate received my father's response, he promptly charged him with insubordination. There was no inquiry or investigation; that was reserved for white civil servants. The magistrate simply deposed my father, thus ending the Mandela family chieftainship. I was unaware of these events at the time, but I was not unaffected. My father, who was a wealthy nobleman by the standards of his time, lost both his fortune and his title. He was deprived of most of his herd and land, and the revenue that came with them (ibid.).

Examples like the ones given above give us clear clues that a great action drama is going to be played in the life of the central figure of this long and difficult journey.

\subsubsection{Part Two: Johannesburg}

a. Sub-parts: 9-10, Pages: 73-106

After his escape from the rural atmosphere, Mandela is introduced to a totally new world. He goes to Johannesburg which is the title of part two of this unit of analysis. Looking at the structure of the book typographically, a reader can feel the signposts of a long journey. The titles of the various parts take us step by step from one post to another. Born and raised in a poverty stricken locality, Mandela bumps into a world of wealth and fashion. He is completely astonished and absorbed into the colors of wealth and happiness of Johannesburg. Part two has rightly been captioned as "Johannesburg" as this city becomes the permanent abode of this truly homo politicus.

\section{b. Topics related to Categories of Wealth, Poverty and Financial Matters}

From here the real story of the long walk begins. Johannesburg has been the spring board of Nelson Mandela as far as the Black movement of freedom is concerned. The name and term Johannesburg itself is symbolic and tells us about the great struggle of the African National Congress (ANC) leadership and the common people who were tortured and punished severely just for asking for their rightful demands. The city of Johannesburg cannot be ignored when and wherever there is a mention of the great freedom movement in South Africa.

Johannesburg also introduces Nelson Mandela to the great wealth, especially the gold mines in the city and stirs 
his mind to think about the wealth of his country and the share of his race in this huge wealth. Impressed with the opulence of the city and at the same time disturbed by the poverty of his people, Nelson Mandela decides to have some source of earning in this city. Here, in this city Mandela also intends to meet one of the central leaders of ANC, Dr. A. B. Xuma. The city gifts to him the companionship of Walter Max Ulyat Sisulu. Sisulu who was a real-estate agent and an anti-apartheid activist at the time he met Nelson Mandela. Mr. Sisulu had been a very active member of African National Congress (ANC) and was elected as Secretary General as well as Deputy President of the party at various times. He remained in the prison on Robben Island for twenty-five long years. The city, like a mother extends helping hands to Mandela. He gets a house and a job to start life here. Johannesburg and the life in the city together begin to prepare the young Mandela for the great events to come in his future endeavors. He goes through very tough time with life in extreme poverty and great struggle for survival but at the same time all these troubles give him both physical and mental strength.

The representative words in this part have history, each of them being an individual history, has a long story to tell. So, words like wealth, gold, miserable inequality, job, separation and the like tell us a story like a living being. The terms used by the author tell us a story in the way he directs us and the words full of meaning interact with us while reading his autobiography. Look at the words in context:

Only the presence of cheap labor in the form of thousands of Africans working long hours for little pay with no rights made gold-mining profitable for the mining houses - white-owned companies that became wealthy beyond the dreams of Croesus on the backs of the African people. I had never seen such enterprise before, such great machines, such methodical organization, and such backbreaking work. It was my first sight of South African capitalism at work, and I knew I was in for a new kind of education (p. 50).

Another example among many other is as follows:

That first morning at the firm, a pleasant young white secretary, Miss Lieberman, took me aside and said, "Nelson, we have no color bar here at the law firm." She explained that at midmorning, the tea-man arrives in the front parlor with tea on a tray and a number of cups. "In honor of your arrival, we have purchased two new cups for you and Gaur," she said. "The secretaries take cups of tea to the principals, but you and Gaur will take your own tea, just as we do. I will call you when the tea comes, and then you can take your tea in the new cups." She added that I should convey this message to Gaur. I was grateful for her ministrations, but I knew that the "two new cups" she was so careful to mention were evidence of the color bar that she said did not exist. The secretaries might share tea with two Africans, but not the cups with which to drink it (p. 52).

The above discussion and examples fully support Van Dijk's theory of PDA as he presents in his paper and talks about the domain of politics. Among other topics he clearly discusses systems and relations:

We see that ultimately the definition of political discourse can hardly escape the definition of the very notion of 'politics' itself. This paper cannot do such a complex job, of course, also because there is not a single and unambiguous definition of what 'politics' is. Indeed, the whole discipline of political science is the answer to such a question. And depending on studies in political science, politics may thus not only include all official or unofficial political actors, events, encounters, settings, actions and discourses, but also, ignore abstractly, political processes (like 'perestrojka'), political systems (like democracy and communism), political ideologies (like liberalism), and political (group) relations (such as power, inequality, hegemony, and oppression). In all these cases, the polity not only involves political actors, events, relations, practices or properties, but also social, economic and cultural ones. (1995)

\subsubsection{Part Three: Birth of a Freedom Fighter}

a. Sub-parts: 11-14, Pages: 109-161

The politicization of Nelson Mandela begins unconsciously. During his trials and tribulations in the city of wealth and poverty, the would-be central figure of the ANC and a great freedom fighter begins to feel suffocated and imprisoned. Every day and every moment he faced humiliation and indignities. People of his race were looked down upon and treated in a very unacceptable way as far as human dignity is concerned. Mandela sees no other way to fight against such indignities except political struggle and defiance of the illegitimate authority of the minority ruling class.

\section{b. Topics related to Categories of Politics and Struggle}

In this part, very relevant words and terminology like apartheid, human dignity, political development, mineworkers' strike, government's ruthless retaliation, African mineworkers' union and leadership have been used to express the intended theme. 
The intentional special use of words and their networking combine to produce a collective effect which directly affect the mind of the readers. The special combination of verbs, nouns with specific reference from history like change, 1940's, Atlantic Charter, Nationalists: English second place, South Africa-Whiteman's country forever, Nationalists won: who our enemies are, General Smuts: Apartheid-crazy concept born of prejudice, Bantu authorities act and Civil disobedience idea fully help the writer to control, manipulate and direct the text to his own benefit. Development of his public relation and broadening of his acquaintances and friendship circles give Mandela new energy to be up-n-moving on the great active tracks of freedom fighters at that time. The drama in the language of the living words:

Discrimination $\rightarrow$ humiliation $\rightarrow$ indignities $\rightarrow$ politicization $\rightarrow$ Politics $\rightarrow$ struggle

A look at the words used show that these lead us through the eventful life of the great fighter and give us a pictorial representation with semiotics of all the events of this long and tiring struggle.

\subsubsection{Part Four: The Struggle is My Life}

a. Sub-parts: 15-22, Pages: $165-229$

Stepping into the mire and moving towards the first step of climax, Mandela tells us about the real struggle. As he moves forward, words and phrases change accordingly, i.e., Road to freedom, passive resistance, apartheid, oppression, oppressed and liberation are some of the words and phrases that appear prominently in part four.

Keywords and phrases in this part are as follows:

Road to freedom $=$ oppression $\rightarrow$ apartheid $\rightarrow$ passive resistance

Passive resistance was a prelude to the active resistance which resulted in violence and active struggle against and defiance of the apartheid regime.

\section{b. Topics related to Categories of Struggle}

The real task begins now. The African National Congress holds election for a new president and new plans are thought about keeping in view the government response and reaction to the activities of the ANC. Mandela is now fully involved in the law practice. After working for other law firms for some time he and his friend Tambo establish their own law set up which proves to be a great success. The government has its own agenda. It continues to act upon its policies of apartheid and oppression. Displacement of people and re-location of towns are some of the features of these policies. The themes of oppression and defiance are prominent in this part of the book. All the documents and historical facts are made part of this in a language most suitable for the intended ideas of the writer of this autobiography.

The title "The Struggle is My Life" serves as a signpost for the readers telling them where to go now. The real fight is seen at this stage of the story. Although this is a real-life story of a freedom fighter, if the readers begin at any stage to disbelieve some statements or events, their disbelief is suspended through the use of carefully chosen words and phrases.

\subsection{Step 3: Clustering of Topics/Themes \& Consolidation of Frequencies}

While systemizing all the above data, the researchers have consolidated all the topics and themes in the following table. Frequency of each topic/ theme is also written with them.

Table 3. Presenting topics and themes and their frequencies in a consolidated form

\begin{tabular}{|c|c|c|c|}
\hline S. No. & Main Field & Topics and themes with frequencies & Total \\
\hline 1. & Age Factor & Age: 49 Old: 164 & 213 \\
\hline 2. & Agency & Agencies: 1 Informer: 3 CIA: 4 & 8 \\
\hline 3. & Arrest & Arrests: 15 Arrest: 59 Arrested: 66 Arresting: 3 & 143 \\
\hline 4. & Book & Book: 28 Books: 30 Novel: 2 Novels:4 Poem: 1 & 66 \\
\hline 5. & Bureaucrat & Bureaucrat: 1 & 1 \\
\hline 6. & Business & Business:16 & 16 \\
\hline 7. & Capital & Capital:13 City: 67 & 80 \\
\hline 8. & Co-curricular Activities & Co-curricular Drama: 2 Students Christian association: 2 Gettysburg address: 1 & 5 \\
\hline 9. & People & People: 600 & 600 \\
\hline 10. & Communication & Communication: 22 Communications: 11 Communicate: 12 Communicated: 5 & 50 \\
\hline 11. & Conflict & Conflict: 13 Conflicts: 1 & 14 \\
\hline 12. & Constitution & Constitution: 47 Charter: 52 & 99 \\
\hline 13. & Corruption & Corruption: 4 Corrupt: 1 & 5 \\
\hline 14. & Country & Country: 223 Countries: 10 & 233 \\
\hline
\end{tabular}




\begin{tabular}{|c|c|c|c|}
\hline 15. & Crime & Crime: 34 Criminal: 21 Crimes: 10 & 65 \\
\hline 16. & Culture & Culture: 23 Cultures: 1 Cultural: 6 & 30 \\
\hline 17. & Custom & Custom: 14 Customs: 6 & 20 \\
\hline 18. & Discrimination & Discrimination: 9 Discriminatory: 4 & 13 \\
\hline 19. & Disease & Disease: 1 Diseases: 1 Teeth problems: 2 Heel problem: 6 & 10 \\
\hline 20. & Economy & Economy: 6 Economic: 23 & 29 \\
\hline 21. & Education & Education: 83 Educational: 3 Educate: 6 Educated: 16 & 108 \\
\hline 22. & Employment & Employment: 1 Job: 20 & 21 \\
\hline 23 & Equality & Equality: 10 Equal: 22 Equals: 5 & 37 \\
\hline 24. & Environment & Environment: 3 & 3 \\
\hline 25. & Evolution & Evolution: 5 & 5 \\
\hline 26. & Family & $\begin{array}{l}\text { Family: } 136 \text { Families: } 24 \text { Father: } 107 \text { Mother: } 100 \text { Wife: } 101 \text { Sister: } 25 \text { Child: } \\
38 \text { Children: } 101 \text { Son: } 63 \text { Sons: } 11 \text { Daughter: } 46 \text { Daughters: } 7 \text { Granddaughter: } 1 \\
\text { Grandchildren: } 7\end{array}$ & 767 \\
\hline 27. & Food & $\begin{array}{l}\text { Food: } 87 \text { Mealie: } 8 \text { Mealies: } 14 \text { Samp: } 6 \text { Meat: } 19 \text { Rice: } 10 \text { Seafood: } 1 \text { Tea: } 30 \\
\text { Bread: } 21\end{array}$ & 196 \\
\hline 28. & Freedom & Freedom: 234 Liberty: 7 Liberation: 51 Free: 123 & 415 \\
\hline 29. & Friendship & Friend: 54 Friends: 68 Friendship: 11 Friendly: 17 & 150 \\
\hline 30. & Goodness & Goodness: 5 & 5 \\
\hline 31. & Government Official & Government Official: 37 Officials: 32 & 69 \\
\hline 32. & Health & Health: 18 & 18 \\
\hline 33. & History & History: 95 Historical: 8 Historic: 8 Historically: 3 & 114 \\
\hline 34. & House & House: 180 Houses: 33 & 213 \\
\hline 35. & Human Rights & Human Rights: 6 Rights: 56 & 62 \\
\hline 36. & Humiliation & Humiliation:1 Humiliations:2 Humiliating: 8 Humiliate: 1 Humiliate: 1 & 13 \\
\hline 37. & Identity & Identity: 14 & 14 \\
\hline 38. & Ideology & Ideology: 4 Ideologies: 2 & 6 \\
\hline 39. & Indigenous & Indignities: 5 & 5 \\
\hline 40. & Inequality & Inequality: 4 & 4 \\
\hline 41. & Immigration & Immigration: 2 Migrant: 2 & 4 \\
\hline 42. & Institution & Institutions: 7 Institution: 7 Council: 34 Government: 453 Parliament: 48 & 549 \\
\hline 43. & International Politics & International Politics International: 49 Sanctions: 30 & 79 \\
\hline 44. & Job & Job opportunities: 12 & 12 \\
\hline 45. & Justice & Justice: 45 Unjust: 7 Injustice: 7 Injustices: 1 & 60 \\
\hline 46. & Language & Language: 38 English: 61 Afrikaans: 28 & 127 \\
\hline 47. & Law & Law: 160 Laws: 46 Legal: 59 Illegal: 23 Legally: 3 Illegally: 10 & 301 \\
\hline 48. & Leader & Leader: 66 Leaders: 100 & 166 \\
\hline 49. & Literary & Literature: 6 Mqhayi: 10 & 16 \\
\hline 50. & Love & Love: 39 & 39 \\
\hline 51. & Media & Media: 7 Newspaper: 45 Newspapers: 36 Television: 10 Radio: 22 BBC: 2 & 122 \\
\hline 52. & Moderation & Moderation: 3 & 3 \\
\hline 53. & Morality & Moral: 26 Immoral: 6 & 32 \\
\hline 54. & National Interest & Interests: 22 Interest: 26 & 48 \\
\hline 55. & Organization & Organization: 199 Organizations: 38 & 237 \\
\hline 56. & Peace & Peace: 45 Peaceful: 11 Peacefully: 3 & 59 \\
\hline 57. & People's Behavior & Behavior: 28 & 28 \\
\hline 58. & Police & Police: 231 & 231 \\
\hline 59. & Personal Life & Personal: 19 Life: 210 Lives: 34 & 263 \\
\hline 60. & Personal Traits & Personal traits Strength: 29 & 29 \\
\hline 61. & Policy & Policy: 101 Policies: 27 & 128 \\
\hline 62. & Political Action & $\begin{array}{l}\text { Political Action Protest: } 81 \text { Protests: } 17 \text { March: } 18 \text { Strike: } 84 \text { Strikes: } 20 \text { Mass: } \\
63 \text { Campaign: } 178 \text { Boycott: } 18 \text { Action: } 99 \text { Defiance: } 57 \text { Disobedience: } 12\end{array}$ & 647 \\
\hline 63. & Political Actors & $\begin{array}{l}\text { Political Actors Politician: } 8 \text { Politicians: } 10 \text { President: } 109 \text { Presidents: } 7 \text { Prime } \\
\text { minister: } 41 \text { Prime ministers: } 1\end{array}$ & 176 \\
\hline 64. & Parties & $\begin{array}{l}\text { Political Party: } 208 \text { Parties:26 ANC: } 679 \text { PAC: } 89 \text { NP: } 1 \text { Nationalists: } 30 \\
\text { Inkatha: } 38 \text { Pan Africanist: } 5 \text { African National Congress: } 23\end{array}$ & 1099 \\
\hline 65. & Political Legislation & Political Legislation: 19 Elect: 5 Vote: 43 Voting: 21 Voted: 14 Election: 61 & 163 \\
\hline 66. & Political relations & Political Relations Apartheid: 93 Separate: 57 Separation: 1 & 151 \\
\hline 67. & Political Rights & Political Rights: 4 & 4 \\
\hline 68. & Politics & Politics: 57 & 57 \\
\hline 69. & Poverty & Poverty: 19 Poor: 42 Worker: 13 Workers: 42 & 116 \\
\hline 70. & Power & Power: 80 & 80 \\
\hline 71. & Race & $\begin{array}{l}\text { Race: } 23 \text { Racial: } 30 \text { Racism: } 10 \text { Racist: } 15 \text { Black: } 188 \\
\text { Blacks: } 33 \text { White: } 374 \text { Whites: } 112 \text { Indian: } 90 \text { Indians: } 52 \text { Coloured: } 56 \\
\text { Coloureds: } 32\end{array}$ & 1015 \\
\hline 72. & Reading & Reading: 30 & 30 \\
\hline 73. & Religion & Religion: 12 God: 17 Christ: 2 Religious: 11 Christian: 21 Christians: 2 Muslim: & 125 \\
\hline
\end{tabular}




\begin{tabular}{|c|c|c|c|}
\hline & & Muslims: 1 Methodist: 11 Methodists: 1 Church: 46 & \\
\hline 74. & Revolution & Revolution: 14 Revolutionary: 19 Revolutionaries: 3 & 36 \\
\hline 75. & Science & Science: 15 & 15 \\
\hline 76. & Secularism & Secular: 1 & 1 \\
\hline 77. & Security & Security: 69 & 69 \\
\hline 78. & Sports & Sports: 3 Boxing: 11 Exercise: 26 Play: 8 & 48 \\
\hline 79. & Status & Status: 11 & 11 \\
\hline 80. & Struggle & Struggle: 240 & 240 \\
\hline 81. & Sympathy & Sympathy: 2 Sympathetic: 24 Sympathize:1 Sympathized: 4 & 31 \\
\hline 82. & Systems & $\begin{array}{l}\text { Democracy: } 29 \text { Democratic: } 45 \text { Undemocratic: } 4 \\
\text { Communism: } 39 \text { Communist: } 94\end{array}$ & 211 \\
\hline 83. & Terrorism & Terrorism: 12 Terrorist: 3 Terrorists: 4 & 19 \\
\hline 84. & Time & Time: 439 & 439 \\
\hline 85. & Tolerance & Tolerance: 2 Tolerant: 2 Tolerate: 6 & 10 \\
\hline 86. & Trade & Trade: 33 & 33 \\
\hline 87. & Tradition & Tradition: 8 Traditional: 43 & 51 \\
\hline 88. & Tribe & Tribe: 23 Tribes: 13 Tribal: 29 Xhosa: 82 Zulu: 29 & 176 \\
\hline 89. & Travel & $\begin{array}{l}\text { Travel: } 13 \text { Travels: } 8 \text { Traveling: } 9 \text { Drive: } 41 \text { Driving: } 20 \\
\text { Drove: } 46 \text { Driven: } 20\end{array}$ & 157 \\
\hline 90. & Unemployment & Unemployment: 1 & 1 \\
\hline 91. & Values & $\begin{array}{l}\text { Values: } 8 \text { Virtue: } 6 \text { Virtues: } 2 \text { Generosity: } 14 \text { Heroism: } 2 \text { Humility: } 3 \text { Manhood: } \\
10 \text { Courage: } 23 \text { Bravery: } 3\end{array}$ & 71 \\
\hline 92. & Violence & Violence: 123 Violent: 20 & 143 \\
\hline 93. & War & War: 76 Wars: 4 & 80 \\
\hline 94. & Weapons & Gun: 13 Guns: 9 Pistol: 3 Weapon: 9 Weapons: 26 & 60 \\
\hline 95. & World Powers & Britain: 12 China: 7 Soviet Union: 8 America: 8 France: 2 & 37 \\
\hline
\end{tabular}

The researchers are of the view that words along with social and historical contexts have strong relationship. Language grows and "socializes" in the society and develops or declines with the passage of time. Social relationship and interaction play their role in developing specific meanings of the words of a language. Linguistic devices used in a language in particular circumstances also follow the social relationship among people and the historical context.

Guerin (1997) says:

The main issue with talking about devices for conversation or text is that the analyses seem to reside in the words rather than the social context or social relationships, as if we can analyse the words without the social relationships. While most sociolinguists would not agree with such a statement put this boldly, the view remains implicit and easily taken on board by others.

Guerin further (2007) says:

An important point to remember from this, mentioned earlier, is that the social analysis does not reside in words. The real events happening in such situations are in the social relationships and the histories of social relationships. If I remark, "put that down or you are going to be in a lot of trouble," it is not the words that make things happen here, but our relationship and history and the likely consequences to our relationship or the immediate situation between us if you were to not put it down. So even though words might be used, the power for anything to happen comes from the social relationships and their past and present consequences. This is what game theory is all about, and provides a good way to analyze the "verbal" strategies being highlighted here. But the analysis is more than that.

Now when we re-arrange the themes according to their highest frequency, we can clearly see the frequently appearing themes which show the whole drama of the author's eventful life in its specific context. As a political leader, his life and mission are very clear. The themes of political parties, race, family, political action and common people are the first five highest frequency themes. The re-arrangement is presented in the following graph: 


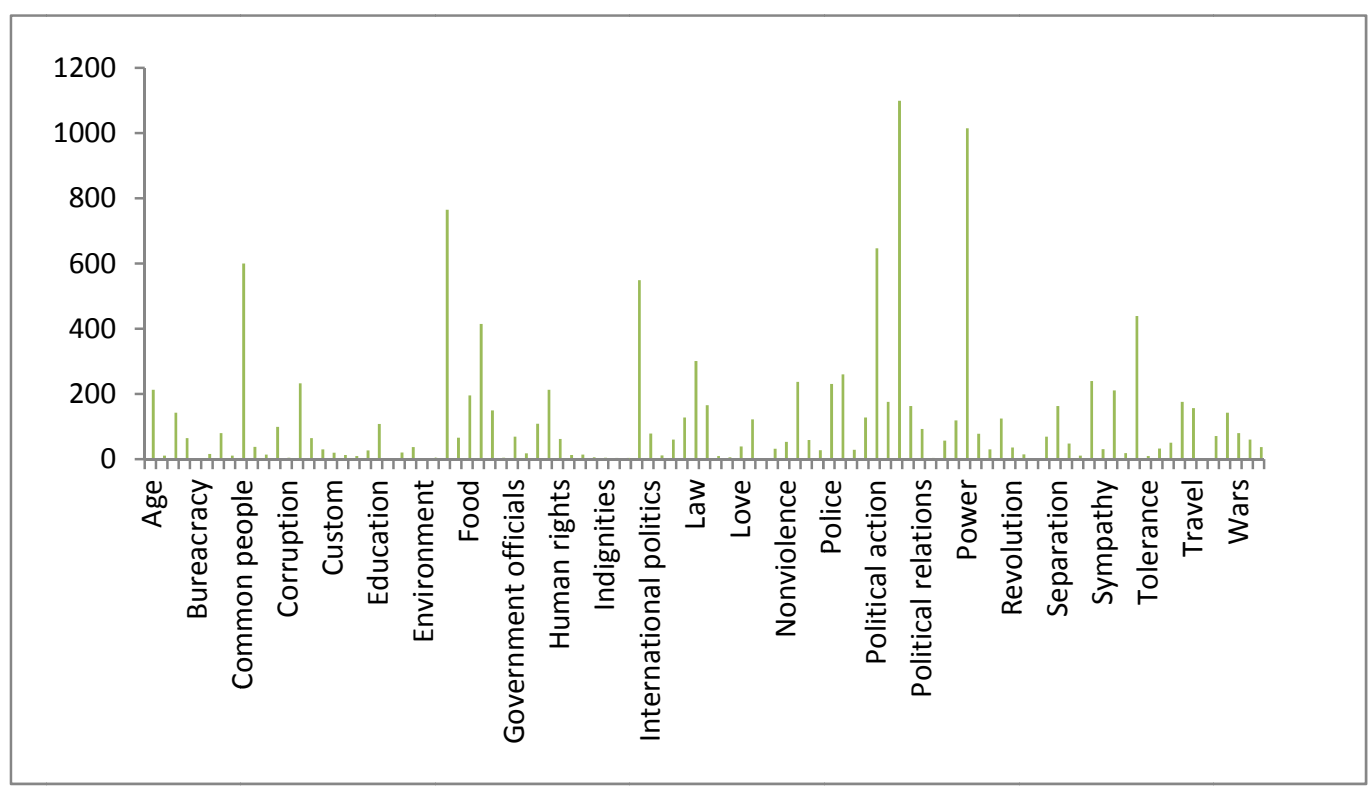

Figure 1. Graphic representation of the themes in Long Walk to Freedom

The themes this study explored show the influence of the historical context. Ten most frequent themes in the text reveal the influence of history. This influence is obvious from the following tables:

Table 4. Ten most frequent themes in Long Walk to Freedom

\begin{tabular}{lllllllllll}
\hline Theme & $\begin{array}{l}\text { Political } \\
\text { Parties }\end{array}$ & Race & Family & $\begin{array}{l}\text { Political } \\
\text { Action }\end{array}$ & $\begin{array}{l}\text { Common } \\
\text { People }\end{array}$ & Institutions & Time & Freedom & Law & $\begin{array}{l}\text { Personal } \\
\text { Life }\end{array}$ \\
\hline Frequency & 1099 & 1015 & 765 & 647 & 600 & 549 & 439 & 415 & 301 & 260 \\
\hline
\end{tabular}

In the Long Walk to Freedom when we frame the whole text in a certain period, it shows the struggle between the dominant and the dominated. The themes of inequality, race, and poverty, denial of universal and democratic rights dominate. The policy of separation is expressed in the words of the oppressor and intentionally not translated as an effective linguistic device which gives the impression of unjust domination over the native people by foreign forces. The term "apartheid" has been made a living word which shows its very nature of discrimination by the manipulation of the text around it.

Look at the framing of the whole text of Long Walk to Freedom in the following diagram:

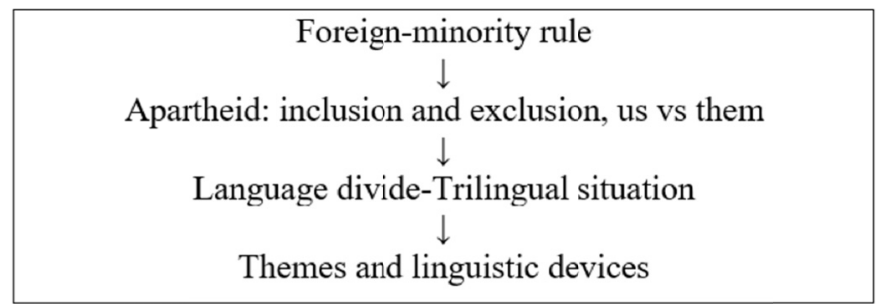

Figure 2. Framing: struggle against Apartheid and foreign-minority rule1945-1990

Long Walk to Freedom is a memoire/autobiography by a freedom fighter who spent twenty-seven years and five months in prison for his political beliefs. Before his sixtieth birthday his colleagues in the prison suggested him to write his memoirs, however the first draft was not published and the present volume is based on that first draft. Mandela says:

From there, the trail grows cold. I heard nothing from Lusaka about the manuscript and still do not know 
precisely what Oliver did with it. Although it was not published while I was in prison, it forms the spine of this memoir (p. 420).

The basic purpose of that first draft of memoirs was to present to people and young freedom fighters, their entire struggle for freedom and the purpose of their struggle against the apartheid regime. He writes in the book:

One day, Kathy, Walter, and myself were talking in the courtyard when they suggested that I ought to write my memoirs. Kathy noted that the perfect time for such a book to be published would be on my sixtieth birthday. Walter said that such a story, if told truly and fairly, would serve to remind people of what we had fought and were still fighting for. He added that it could become a source of inspiration for young freedom fighters. The idea appealed to me, and during a subsequent discussion, I agreed to go ahead (p. 416).

The above extract from the main text tells us that intention was to write memoirs in the shape of a story in order to inspire young freedom fighters. Simply, we can put this in the following way:

Memoirs $\rightarrow$ Story $\rightarrow$ Inspiration

That is:

Genre: Memoirs/autobiography

Structure: Story

Purpose: Inspiration

About writing the memoirs and the selection of words and phrases Mandela writes: "I wrote rapidly, completing a draft in four months. I did not hesitate over choosing a word or phrase. I covered the period from my birth through the Rivonia Trial, and ended with some notes about Robben Island" (pp. 16-17).

Again, Mandela tells us about his experience and internal feelings while writing his autobiography:

I relived my experiences as I wrote about them. Those nights, as I wrote in silence, I could once again experience the sights and sounds of my youth in Qunu and Mqhekezweni; the excitement and fear of coming to Johannesburg; the tempests of the Youth League; the endless delays of the Treason Trial; the drama of Rivonia. It was like a waking dream and I attempted to transfer it to paper as simply and truthfully as I could (p. 417).

Long Walk to Freedom is a blend of personal life which includes the purely domestic life, romantic life of the author, his initial adventures, professional life, political journey, description of nature and history. Summarily, this long story or his-story can be presented as follows:

Birth and parentage $\rightarrow$ Death of father $\rightarrow$ Life at Grand Place $\rightarrow$ Clarkebury, Healdtown and Fort Hare $\rightarrow$ Flight to Johannesburg $\rightarrow$ Initial difficulties and accommodation $\rightarrow$ Legal studies and practice $\rightarrow$ Marriage, marriage break-up and romance with Winnie Mandela $\rightarrow$ Political connections $\rightarrow$ Full political involvement $\rightarrow$ Creation of Umkhonto We Sizwe $\rightarrow$ Rivionia trial and life imprisonment $\rightarrow$ Robben Island $\rightarrow$ Release and Democratic, non-racial South Africa $\rightarrow$ First black president

\subsection{Linguistic Devices Used in the Texts of Long Walk to Freedom}

Various linguistic devices are used in the text of the selected unit of analysis. The forthcoming discussion would highlight some prominent devices. The unique and effective use of the year-statistics in the autobiography makes the whole story and its flow easy to understand. In Long Walk to Freedom the author also makes effective use of the language of the minority regime, that is, Afrikaans, to manipulate the discourse towards the positive image of the author and his party and negative image of the protagonists. The use of the African language makes the message of the author potent and easy to understand. Some of the linguistic devices were also found to have been quite common with the ones used by Barack Hussein Obama in his autobiography The Audacity of Hope (same genre). The Trilingual combination, use of the dramatic language and listing or cluster of three to stress certain themes have been found. The themes of racial discrimination, inequality, poverty, parties, law, justice, separation and history are common and are stressed. The use of the term "Apartheid" instead of translated word 'apartness' or 'separation' in Long Walk to Freedom and the term "Nigger" instead of translated word 'black' in The Audacity of Hope give the feelings of foreign element and history in their respective context. 
Table 5. Linguistic devices in Long Walk to Freedom

\begin{tabular}{ll}
\hline S. No. & Linguistic Device \\
\hline 1. & Abusive Language \\
2. & Adjectives \\
3. & African/Xhosa/Native Language \\
4. & Afrikaans Language \\
5. & Backgrounding \\
6. & Cluster of Three \\
7. & Comparison/opposites \\
8. & Deletion \\
9. & Description of statistics \\
10. & Dialogue/Dramatic language \\
11. & Family/affection words \\
12. & Foregrounding \\
13. & Idioms \\
14. & Imperatives \\
15. & Instances of the word "thousand" in the text \\
16. & Linguistic Devices and Us vs Them \\
17. & Listing \\
18. & Metaphor \\
19. & Numerical Data \\
20. & Simile \\
21. & Statistics \\
22. & Personification \\
23. & Presupposition \\
24. & Pronouns \\
25. & Racial Nouns/Adjectives \\
26. & Topicalization \\
\hline &
\end{tabular}

The text uses first person pronoun more than any other pronoun. The style of Long Walk to Freedom is like a novel with protagonist as the narrator himself and the antagonist as the apartheid regime and the discriminatory laws or legal system. This style is itself a linguistic device for catching reader's attention from the very beginning. Style and narrative technique as a linguistic device are the direct effect of the historical circumstances and context. Basic purpose of the autobiography of Nelson Mandela, according to him, was to "inspire" the young people and for this purpose the style of a story-telling was adopted. First, we look at the super structures of the text selected for this study. The detail has been given below:

\subsubsection{Superstructure or Textual 'Schemata'}

The superstructure or Schema (plural schemata) is also important part of the Political Discourse Analysis. According to Van Dijk's theory of PDA, political discourse follows the traditional organization of argumentation, stories and news reports. Meanings become prominent for partisan reasons. Distribution of meanings in discourse shows information in a caption or headline, summary or in a conclusion.

In case of Long Walk to Freedom the very caption or title of the book tells us the whole story told in the book. As this autobiography was written to "inspire" the young generation, this long story not only follows the traditional schemata of the story but also amalgamate the colors or elements of the novel and drama in order to catch the attention of the reader and carry him or her along by using linguistic devices that not only create the effects of thrill and action but also arouse the emotions of sympathy in the hearts and minds of the readers towards author and his party or ideological group and hate towards his opponents or enemies. Diagrammatically it can be presented as under:

Long Walk to Freedom $\rightarrow$ Meaningful heading or caption which tells the whole story

$$
\downarrow
$$

Part One: A Country Childhood

$$
\downarrow
$$

Part Two: Johannesburg 
Part Three: Birth of Freedom Fighter

$\downarrow$

Part Four: The Struggle Is My Life

$\downarrow$

Part Five: Treason

$\downarrow$

Part Six: The Black Pimpernel

$$
\downarrow
$$

Part Seven: Rivonia

Part Eight: Robben Island: The Dark Year

$$
\downarrow
$$

Part Nine: Robben Island: Beginning to Hope

Part Ten: Talking with the Enemy

\section{Part Eleven: Freedom}

There are 115 sub-parts into which the whole text has been divided. Every sub-part is captioned with a cardinal number with no title in words. This structuring of the text facilitates the reader as well as helps in manipulation of the text and control by the author over the text. The natural consequence of which is the control over meaning and the reader.

Look at the diagram following the cardinal numbers. They appear as the milestones/signposts/relief spots.

Sub-parts:

From slavery Part One $1 \rightarrow 2 \rightarrow 3 \rightarrow 4 \rightarrow 5 \rightarrow 6 \rightarrow 7 \rightarrow 8 \rightarrow$ Part Two $\rightarrow 9 \rightarrow 10 \rightarrow$ Part Three $\rightarrow 11 \rightarrow 12 \rightarrow 13 \rightarrow$ $14 \rightarrow$ Part Four $\rightarrow 15 \rightarrow 16 \rightarrow 17 \rightarrow 18 \rightarrow 19 \rightarrow 20 \rightarrow 21 \rightarrow 22 \rightarrow$ Part Five $\rightarrow 23 \rightarrow 24 \rightarrow 25 \rightarrow 26 \rightarrow 27 \rightarrow 28 \rightarrow$ $29 \rightarrow 30 \rightarrow 31 \rightarrow 32 \rightarrow 33 \rightarrow 34 \rightarrow 35 \rightarrow 36 \rightarrow 37 \rightarrow 38 \rightarrow 39 \rightarrow$ Part Six $\rightarrow 40 \rightarrow 41 \rightarrow 42 \rightarrow 43 \rightarrow 44 \rightarrow 45 \rightarrow 46 \rightarrow$ $47 \rightarrow 48 \rightarrow$ Part Seven $\rightarrow 49 \rightarrow 50 \rightarrow 51 \rightarrow 52 \rightarrow 53 \rightarrow 54 \rightarrow 55 \rightarrow 56 \rightarrow 57 \rightarrow 58 \rightarrow$ Part Eight $\rightarrow 59 \rightarrow 60 \rightarrow 61 \rightarrow$ $62 \rightarrow 63 \rightarrow 64 \rightarrow 65 \rightarrow 66 \rightarrow 67 \rightarrow 68 \rightarrow 69 \rightarrow 70 \rightarrow$ Part Nine $\rightarrow 71 \rightarrow 72 \rightarrow 73 \rightarrow 74 \rightarrow 75 \rightarrow 76 \rightarrow 77 \rightarrow 78 \rightarrow 79 \rightarrow$ $80 \rightarrow 81 \rightarrow 82 \rightarrow 83 \rightarrow 84 \rightarrow 85 \rightarrow 86 \rightarrow$ Part Ten $\rightarrow 87 \rightarrow 88 \rightarrow 89 \rightarrow 90 \rightarrow 91 \rightarrow 92 \rightarrow 93 \rightarrow 94 \rightarrow 95 \rightarrow 96 \rightarrow$ $97 \rightarrow 98 \rightarrow 99 \rightarrow$ Part Eleven $\rightarrow 100 \rightarrow 101 \rightarrow 102 \rightarrow 103 \rightarrow 104 \rightarrow 105 \rightarrow 106 \rightarrow 107 \rightarrow 108 \rightarrow 109 \rightarrow 110 \rightarrow$ $111 \rightarrow 112 \rightarrow 113 \rightarrow 114 \rightarrow 115$ To Freedom

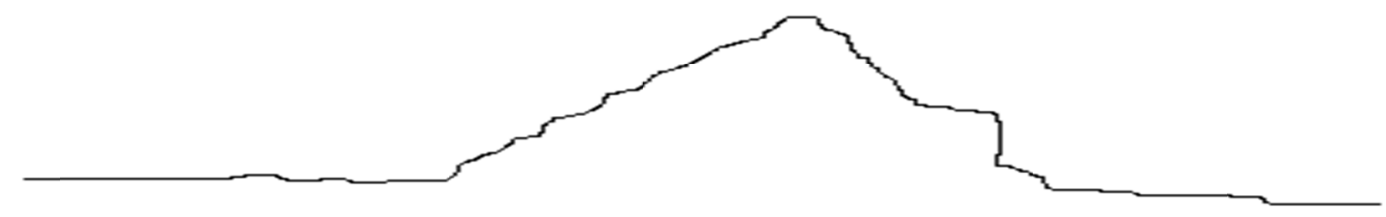

Figure 3. Long walk or struggle drama in Long Walk to Freedom

The above structure of the text shows that it is intentionally and systematically created structured arrangement which in itself is an effective superstructure and linguistic device. If we look at the arrangement of the sub-parts numbers above, we can see a long road with signposts and rest of the areas in the shape of sub-parts division 
captioned with cardinal numbers. As mentioned before, numerical data plays a very important role in Long Walk to Freedom as far as the direction and the whole schemata of the text are concerned. Every part gives a summary in the shape of its heading and systematically carries the reader along by dividing each part into sub-parts. This superstructure and schema are very effective in manipulating the text.

\subsubsection{Use of Year Statistics in Long Walk to Freedom}

To convey his themes effectively and "inspire" the young freedom fighters as he mentions the purpose of this autobiography, Nelson Mandela makes liberal use of statistics including numbers of places, persons and number of occurrences of events. The researchers observe that the author has used years as an effective tool to facilitate walk through history along with Nelson Mandela. The figures of years have appeared 422 times in the text of Long Walk to Freedom. The statistical data have been given in tabulated form below:

Table 6. Years mentioned in the text of Long Walk to Freedom

\begin{tabular}{llllllll}
\hline 1652 & 1658 & $1800 \mathrm{~s}$ & 1819 & 1820 & 1820 & 1825 & 1983 \\
1838 & 1840 & 1879 & 1879 & 1886 & $1900 \mathrm{~s}$ & 1909 & 1974 \\
1912 & 1936 & 1913 & 1914 & 1914 & 1915 & 1832 & 1979 \\
1916 & 1941 & 1917 & 1923 & 1918 & 1927 & 1912 & 1980 \\
$1920 \mathrm{~s}$ & 1943 & 1921 & 1924 & 1926 & 1941 & 1942 & \\
1934 & 1937 & 1939 & $1940 \mathrm{~s}$ & 1941 & $1930 \mathrm{~s}$ & 1944 & \\
1946 & 1949 & 1960 & $1960 \mathrm{~s}$ & 1987 & 1988 & $1970 \mathrm{~s}$ & \\
1948 & 1950 & 1961 & 1962 & 1990 & 1972 & 1975 & \\
$1950 \mathrm{~s}$ & 1951 & 1963 & 1965 & 1991 & 1982 & 1976 & \\
1953 & 1952 & 1964 & 1966 & 1992 & 1989 & $1980 \mathrm{~s}$ & \\
1954 & 1957 & 1967 & 1969 & 1994 & 1973 & 1984 & \\
1956 & 1959 & 1968 & 1970 & 1993 & 1971 & 1981 & \\
1958 & 1960 & 1986 & 1985 & 1999 & 1977 & 1978 & \\
\hline
\end{tabular}

This data show that Nelson Mandela at times goes back in history to the seventeenth century and then continues his journey towards freedom using the years as milestones and direction-posts. The use of years in such a way has deictic qualities and the author takes the reader towards his desired direction.

The table indicates the decades mentioned by the author. This table also shows the number of years appeared in each decade in the text which also indicates the important events occurred in these years and that is why they are worth mentioning. Surprisingly, the author does not refer to the eighteenth century even a single time in the text.

When the data in the above table is converted into a graph shape, we visually see the "Long Walk" that indicates the role of statistical data in effectively presenting the freedom struggle and other themes in the text. Different bars of the graph show the journey of the mind and the practical involvement of the author in events of struggle for freedom. If we look closely at the graph, we can understand the course of struggle and the rise and fall and the climax of the whole drama of life and struggle of the author of the book. The graph indicates that the drama on the South African stage begins during the 1650s. During the early years, the action develops slowly and gradually and then in 1910 s there is a rise in the action which leads to the establishment of the African National Congress or the ANC. The climax of the action reaches during the 1960s with the treason-trial of Nelson Mandela and his companions in which they receive life imprisonment. The falling action starts during the imprisonment of Mandela and other treason-trialists on the Robben Island, and after the release of Nelson Mandela the action heads towards its grand finale. So, the effective use of chronological data in the shape of the year figures gives the whole picture of the theme of freedom struggle.

Look at the following figure: 


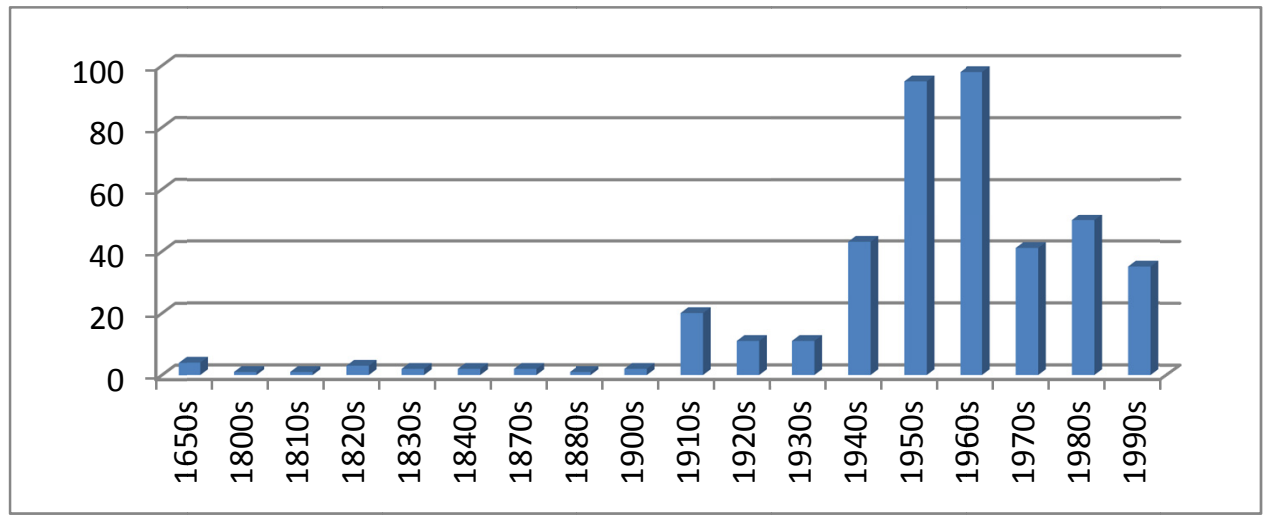

Figure 4. Graphic representation of decades in the text of Long Walk to Freedom

\subsubsection{Use of Numerical Data in Long Walk to Freedom}

Nelson Mandela uses different numerical data to support his claims and to stress a point as a proof of the claim. The following table shows the numbers that appeared in the text.

Table 7. Numerical data appeared in the text

\begin{tabular}{lllll}
\hline 70 & 150 & 250 & 60000 & 120000 \\
80 & 150 & 252 & 700000 & 400000 \\
100 & 230 & 400 & 100000 & 700000 \\
100 & 250 & 8500 & 100000 & \\
108 & 150 & 18000 & 100000 & \\
120 & 250 & 200000 & 100000 & \\
\hline
\end{tabular}

\subsubsection{Description of Statistics in the Text and Hyperbole}

In the body of the text we find many examples of statistics which are comparative and hyperbolic in nature especially involving "million" in most of the cases. They not only emphasize the author's point of view but at the same time also stress the idea of "Us" vs "Them". Look at some of the examples from the text:

1) three and a half million Xhosas and a tiny minority

2) three million whites owned 87 percent of the land

3) eight million Africans to the remaining 13 percent

4) three million whites could participate, but none of the thirteen million Africans

5) crowd estimated at half a million

6) as many as a million people personally witnessed our procession

7) about million-rand payoffs to Inkatha

8) More than four million workers stayed home

9) over twenty million people going to the polls

10) to build a million new houses with electricity and flush toilets

(Done on AntConc on July 7, 2014)

Similarly, instances of appearance of the word "thousand" in the text are in abundance:

1) a thousand rivers and streams

2) with more than a thousand students

3) a prisonlike compound of a few thousand matchbox houses

4) we will wait a thousand years for our freedom 
5) I marched with Gaur, and ten thousand others

6) a steady accumulation of a thousand slights

7) a thousand indignities, a thousand unremembered moments

8) and he had boosted the amount to four thousand pounds

9) No less than two thousand volunteers went to jail

10) drew ten thousand people at Johannesburg's Market Square

11) led a demonstration of five thousand people

12) a vibrant community of more than fifty thousand people

13) About ten thousand people were in attendance

14) Ten thousand people gathered to hear Chief Luthuli speak

15) four thousand police and army troops cordoned off the township

16) which had a total enrollment of ten thousand children

17) handed over their two hundred thousand African students to the government

18) On the east Rand it affected some seven thousand schoolchildren

19) More than three thousand delegates braved police intimidation to assemble

20) twelve thousand in all

21) eight thousand pages of typed evidence and twelve thousand documents to prepare its case

22) All told, more than one thousand women were arrested

23) the number of arrests had increased and nearly two thousand women were incarcerated

24) one of them having recruited about two thousand members

25) the Crown entered some two thousand documents into the record and called two hundred

26) some thirty thousand people, led by the young student Philip Kgosana

27) In the early afternoon, a crowd of several thousand surrounded the police station

28) country responded magnificently as several hundred thousand Africans observed the chief's call

29) In Cape Town a crowd of fifty thousand met in Langa Township to protest the shootings

30) the detention without trial of more than two thousand people

31) five thousand pounds for weapons

32) who not only gave me five thousand dollars for weapons and training

33) asked for five thousand dollars for the support of MK

34) I also had several thousand pounds in cash

35) banished there by the British after leading ten thousand warriors against Grahams town in 1819.

36) Within a few days we learned there were about a thousand men

37) The document set a goal of seven thousand MK recruits in the country

38) Despite the intimidation, as many as two thousand people assembled in front of the courthouse

39) bumping up and down in a plane at fifteen thousand feet seemed far more perilous than being locked

40) known as sections F and G, contained about a thousand mostly common-law prisoners

41) de Wet and General Kemp had led a force of twelve thousand

42) On June 16, 1976, fifteen thousand school children gathered in Soweto to protest

43) It was a moment I had dreamed about a thousand times

44) an occasion is lost in the welter of a thousand details

45) cameras and news people as well as several thousand well-wishers

46) My ten thousand days of imprisonment were over 


\section{7) I addressed a crowd of twenty thousand angry ANC supporters}

48) the strike was a march of one hundred thousand people to the Union Buildings in Pretoria

49) On the morning of September 7, 1992, seventy thousand protesters set out on a march

50) there would be ten thousand polling stations around the country

51) We sought to train over one hundred thousand people to assist with voter education

(Done on AntConc on July 8, 2014)

\subsubsection{Unique Linguistic Devices}

The following unique linguistic devices were also marked:

Table 8. Unique linguistic devices in Long Walk to Freedom

\begin{tabular}{ll}
\hline S. No. & Unique Linguistic Device \\
\hline 1. & Use of cardinal numbers/cardinals \\
2. & Structural manipulation/structures \\
3. & Use of anno-statistics \\
4. & Use of numerical manipulation/numerics \\
5. & Verbal description of statistics with hyperbolic effect/statisto-hyperbole \\
6. & Use of foreign/“language of the enemy'/lingua inimicus \\
7. & Pronominal inclusivity \\
8. & Pronominal exclusivity \\
9. & Racial nouns/noma radix \\
10. & Imperatives \\
\hline
\end{tabular}

The study thus attempted to analyze themes and linguistic devices in political autobiography by South African black freedom-fighter, Nelson Mandela. Findings reveal that various linguistic devices are used in abundance. Amongst the most prominent ones are the unique and effective use of the year-statistics, language of the minority regime, Afrikaans, Trilingual combination, dramatic language and listing or cluster of three to stress certain specific themes like racial discrimination, inequality, poverty, parties, law, justice, separation and history.

\section{Recommendations for Future Research}

This research will prove a pioneering work in the genre of its unit of analysis and a trend setter as far as the research in political discourse analysis is concerned. The researchers would like to make the following recommendations for prospective researchers:

1) Since not much attention has been paid to this genre at the national as well as the global level, systematic research work and recognizing autobiography as a separate and distinct genre for linguistic studies are required.

2) This study was confined to one unit of analysis, so, it is recommended that more than one unit of analysis may be selected for further research and compared for different themes and other concepts.

3) This research work analyzed one autobiography by black leader from South Africa. Further research can be done on autobiographies of leaders from other regions of the world. The study further recommends that comparative studies of autobiographies, biographies, memoires and similar genres may be carried out and the differences and similarities be brought to the fore.

4) The study further recommends that autobiographies written by leaders in other fields of life, famous personalities as well as ordinary people may also be explored. This will expand the study of this genre and will give boost to the linguistic studies, especially to the discipline of discourse analysis.

5) The study focused on the themes in general and has tried to explore all possible themes in this unit of analysis. The prospective researchers may study in detail one or two themes in detail from different angles in different context.

6) As literature review of this study reveals that some research work has been done on the limited aspects of autobiography in the world, the researchers are of the view that the autobiography is much more than a mere 'narrative of transformation' or a 'persuasive' composition. It needs deeper study and serious attention of the research scholars.

7) The unit of analysis of this study covers the period from the early twentieth century to the early twenty-first 
century. Studies may be carried out to find out themes in the twenty-first century autobiographies and compared with the themes of the twentieth century.

8) Most of the data collection of this study was done manually which is very time-consuming. For limited purposes, the concordance software AntConc and LIWC were used. These were quite useful. The researchers, therefore, recommend the use of these and other softwares to facilitate future researchers.

9) Clustering of the topics into themes is also time-consuming. For this purpose, softwares like NVivo and ATLAS.ti can be used to integrate technology in the autobiographical analysis.

10) Theories of Historical Linguistics can be used to explore history, linguistic changes and the linguistic representation of history through autobiography.

11) Political autobiography is a good blend of language, history and political philosophy. So, this can be an object of research both in Linguistics and Political Science and proper attention be paid to these aspects by the scholars in the above-mentioned fields.

\section{References}

Anthony, L. (2011). AntConc (Version 3.2.2) [Computer Software]. Tokyo, Japan: Waseda University. Retrieved August 31, 2014, from http://www.antlab.sci.waseda.ac.jp/

Baker, C. (2006). Foundations of bilingual education and bilingualism (4th ed.). Cleve-Don: Multingual Matters.

Crystal, D. (1991). A dictionary of linguistics and phonetics (3rd ed.). London: Blackwell.

Fairclough, N. L. (1995). Critical discourse analysis: The critical study of language. Harlow: Longman.

Guerin, B. (1997). Social context for communication: Communicative power as past and present social consequences. In J. Owen (Ed.), Context and communication behavior (pp. 133-179). Reno Nevada: Context Press.

Guerin, B. (2007). Two 'linguistic devices' that require social context: Integrating social and linguistic analysis. Unpublished doctoral dissertation. School of Linguistics and Applied Language Studies.

Johnson, J. (2005). What is discourse? Retrieved August 22, 2013, from http://www.stolaf.edu/dept/cis/wp/johnsoja/works/index.html

Mandela, N. (2003). Long Walk to Freedom. London: Abacus.

O'Halloran, K. A., \& Coffin, C. (2004). Checking Overinterpretation and Under-interpretation: Help from Corpora in Critical Linguistics. In C. Coffin, A. Hewings \& K. A. O'Halloran (Eds.), Applying English grammar: Functional and corpus approaches (pp. 275-297). London: Hodder Arnold.

Obama, B. (2006). The Audacity of Hope. New York, NY: Three Rivers Press.

Tenorio, H. E. (2011.). Critical discourse analysis: An overview. Nordic Journal of English Studies, 10(1), 183210. https://doi.org/10.35360/njes.247

van Dijk, T. A. (1997). What is political discourse analysis? In J. Blommaert \& C. Bulcaen (Eds.), Political linguistics (pp. 53-67). https://doi.org/10.1075/bjl.11.03dij

van Dijk, T. A. (2015). Critical Discourse Analysis. In D. Schiffrin, D. Tannen, \& H. Hamilton (Eds.), The Handbook of Discourse Analysis (2 ${ }^{\text {nd }}$ ed., pp. 352-371). Massachusetts: Blackwell Publisher.

Weintraub, K. J. (1975). Autobiography and historical consciousness. Critical Inquiry, 1(4), 821-848. https://doi.org/10.1086/447818

\section{Copyrights}

Copyright for this article is retained by the author, with first publication rights granted to the journal.

This is an open-access article distributed under the terms and conditions of the Creative Commons Attribution license (http://creativecommons.org/licenses/by/4.0/). 